\title{
BACTERIA IN COMBINATION WITH FERTILIZERS IMPROVE GROWTH, PRODUCTIVITY AND NET RETURNS OF WHEAT (Triticum aestivum L.)
}

\author{
Mubshar Hussain ${ }^{1}$, Zeshan Asgher'1, Muhammad Tahir ${ }^{2}$, Muhammad Ijaz ${ }^{3}$, Muhammad \\ Shahid ${ }^{4}$, Hakoomat Ali ${ }^{1}$ and Abdul Sattar ${ }^{3, *}$ \\ ${ }^{1}$ Department of Agronomy, Bahauddin Zakariya University, Multan, Pakistan; ${ }^{2}$ Department of Environmental \\ Sciences, COMSATS Institute of Information Technology Vehari-Pakistan; ${ }^{3}$ College of Agriculture, BZU, Bahadur \\ Campus Layyah- Pakistan; ${ }^{4}$ Department of Bioinformatics and Biotechnology, Government College University, \\ Faisalabad-38000, Pakistan. \\ *Corresponding author's e-mail: abdulsattar04@gmail.com
}

\begin{abstract}
Plant growth promoting rhizobacteria (PGPR) associate with roots of plants and improve plant growth by utilizing diverse mechanisms like nitrogen fixation, phosphorus solubilization and phytohormone production. Current study was conducted to isolate, characterize, and identify the wheat associated PGPR and investigate the inoculation effect of selected strains for growth promotion of wheat in combination with different levels of chemical fertilizer at two different ecological locations (Multan and Layyah, Pakistan). Among the total 22 bacterial isolates, 11 were positive for acetylene reduction assay (ARA), 9 isolates exhibited $\mathrm{P}$ solubilization activity and 19 bacterial isolates produced growth hormone indole-3-acetic acid (IAA) in culture medium. From these, two bacterial isolates with maximum potential to fix nitrogen, solubilize phosphorous and to produce IAA were identified through 16S rRNA gene sequence analysis as Pseudomonas sp. LYT-1 (accession no. KT933231) and Bacillus sp. MWT-14 (accession no. KT933232). Their performance as PGPR along with different levels of nitrogen (N) and phosphorous (P) chemical fertilizers (0-0, 105-75 and 150-100 NP kg ha-1) was evaluated under field conditions at two different locations (Multan and Layyah) in 2014-15. The experiments were laid out in Randomize Complete Block Design (RCBD). Results indicated that bacterial strain Pseudomonas sp. LYT-1 (with maximum in vitro nitrogenase activity), increased the growth parameters like plant height, chlorophyll contents, productive tillers, spike length and straw yield of wheat at both the locations. The inoculation of Bacillus strain MWT-14 (with highest in vitro phosphate solubilization and IAA production) in combination with $0-0,105-75$ and $150-100 \mathrm{~kg} \mathrm{ha}^{-1} \mathrm{~N}-\mathrm{P}$ fertilizer improved the 1000 -grain weight by $9.8 \%$, $5.4 \%, 4.6 \%$ and $2.1 \%, 6.6 \%, 4 \%$, respectively at Multan and Layyah, and grain yield by $16.3 \%, 12.3 \%, 4.7 \%$ and $17.1 \%$, $14.2 \%, 8.5 \%$, respectively at Multan and Layyah over their respective non-inoculated control treatments. These results concluded that plant growth promoting strains Pseudomonas sp. LYT-1 and Bacillus sp. MWT-14 enhance the growth, productivity and net returns of wheat when used as bio-inoculant along with $30 \%$ reduced of the recommended NP fertilizer dose.
\end{abstract}

Keywords: Phosphate solubilization, nitrogen fixation, hormone production, nutrient use efficiency, rhizosphere, root exudates.

\section{INTRODUCTION}

Wheat is cereal grain food for various countries of the world. The contribution of wheat to the world diet in the form of higher number of calories and protein makes it a more secure diet to human population (Abd-El-Haleem et al., 2009). Increase in the number of people using wheat as staple food has increased its area under cultivation, but average yield is still lower than the potential of wheat cultivars due to many factors including late sowing (Sattar et al., 2010; Hussain et al., 2012 a,b), poor irrigation facilities (Kibe et al., 2006; Rehim et al., 2012) and un-availability of nutrients like nitrogen (Rehman et al., 2014) and phosphorous (P) (Richardson et al., 2009; Rehim et al., 2012; Hussain et al., 2016). Phosphorus, a major among plant essential nutrients, is applied to soil as synthetic fertilizer_produced from the mining of rock phosphate and chemical processing (Richardson et al., 2009). After application to alkaline soil, $\mathrm{P}$ binds with calcium ions to form complex tricalcium phosphate and becomes unavailable for plants. Because of less availability to the plant, it is one the most important limiting factor for growth and development of plant than other macro nutrients (Richardson et al., 2009). Thus, farmers have to apply more and more $\mathrm{P}$ to meet the requirement of the crop productivity. This practice increases the production cost of the farmer and environmental pollution in general. Another option available to farmers is the use of phosphate solubilizing bacteria (PSB) as bio-fertilizer; as these bacteria have the ability to produce organic acids like gluconic, malic, lactic, acetic acids and lower the $\mathrm{pH}$ of surroundings, thereby 
detaching the cations attached to phosphates (Richardson 2001; Khan et al. 2009; Tahir et al., 2013). Likewise N, being macro-nutrient, plays an imperative function in formation of plant cell proteins and other essential bio-molecules and improves the plant vegetative as well as reproductive growth (Shridhar, 2012). Availability of atmospheric $\mathrm{N}$ to plants depends on its conversion into combined form e.g., $\mathrm{NH}_{4}{ }^{+}$ through a process of industrial $\mathrm{N}$ fixation at very high temperature and pressure for synthesis of BNF. Of the total atmospheric N, 60\% is converted to available form through BNF which is not only economically but also environmental friendly than chemical fertilizers (Ladha et al., 1997; Shridhar 2012).

Phytohormone production is another mechanism which PGPR utilize to improve plant growth (Tahir et al. 2013). Auxins, especially IAA play a prime role in growth and development by escalating root area, increasing the moisture and nutrients uptake. Rhizosphere bacteria including Azospirillum, Azotobacter, Bacillus, Enterobacter and Pseudomonas produced significant amount of IAA as major property to improve plant productivity(Tahir et al., 2013). Isolation of Bacillus strains from the rhizosphere of various crops, phosphate solubilization, IAA production in vitro and plant growth promoting potential of Bacillus strains under field conditions have been reported (Tahir et al., 2015; Tahir et al., 2013). In addition, Pseudomonas spp. equipped with plant-beneficial traits like phosphate solubilization, $\mathrm{N}$ fixation, IAA production and bio-control of plant pathogens have been isolated from the rhizosphere of various crops (Babana et al., 2012; Kumar et al., 2012; Pastor et al., 2014; Tahir et al., 2015). Keeping in view all these problems, the objective of the present study was to isolate, characterize the rhizosphere bacteria on the basis of plant growth promoting qualities (phosphate solubilization, $\mathrm{N}$ fixation and IAA producing ability) and to identify the selected isolates through $16 S$ rRNA sequencing. Furthermore, to evaluate the PGPR potential of the selected isolates as bio-inoculant for improvement of growth, productivity and net returns from wheat, field experiments were conducted at two different location (Multan and Layyah) with varying levels of chemical fertilizer ( $\mathrm{N}$ and $\mathrm{P})$.

\section{MATERIALS AND METHODS}

Extraction of wheat associated diazotrophs: Samples of rhizospheric soil collected from wheat field grown at Multan and Layyah were kept under storage at $4{ }^{\circ} \mathrm{C}$ to use for further processes. Diazotrophs were isolated by adding $0.1 \mathrm{~g}$ of root and attached soil into eppendorf tubes $(1.5 \mathrm{~mL})$ poured with $1.0 \mathrm{~mL}$ of semi-solid nitrogen free medium i.e. NFM (Rennie et al., 1982.). Enrichment was carried out by repeated (5 to 6 times) transfer of grown bacterial culture $(25.0 \mu \mathrm{L})$ after $48 \mathrm{~h}$ to fresh NFM containing eppendorf tubes. Afterwards, to get single colonies, cultures were splashed on plates poured with NFM agar plates.

Isolation of wheat associated phosphate solubilizing bacterial isolates: For the isolation of wheat associated phosphate solubilizing bacterial isolate, $1.0 \mathrm{~g}$ of rhizosphere soil was inoculated in test tube filled with $10.0 \mathrm{~mL}$ of sterilized sodium chloride solution $(0.85 \%$, w/v) and thoroughly mixed. This mixture was further diluted (10X) up to $10^{-3}-10^{-5}$ by transferring $1.0 \mathrm{~mL}$ from each tube to the next tube containing $\mathrm{NaCl}$ solution $(0.85 \%$, w/v), and $100 \mu \mathrm{L}$ of the dilution were equally distributed on plates poured with Pikovskaya agar medium (supplemented with insoluble form of phosphorous i.e. tri-calcium phosphate TCP) plates (Pikovskaya, 1948). The plates were kept under incubation at $30^{\circ} \mathrm{C}$ for 7 days. After several hours of incubation, halo-zones were formed around the bacterial colonies which indicate Psolubilization (solubilization of TCP) activity of the bacterial colonies. For further processing, the halo-zones forming bacterial colonies were selected, picked and purified on plates containing fresh Pikovskaya agar medium.

Estimation of nitrogen fixed by wheat associated rhizosphere bacteria: Determination of diazotrophic potential of the rhizosphere bacteria was made through acetylene reduction assay in partially-solid combined carbon medium (CCM; Rennie et al., 1982) and NFM (Okon et al., 1977). Glass tubes (sterilized) of capacity $16.0 \mathrm{~mL}$ were poured separately with $5.0 \mathrm{~mL}$ of semisolid NFM and CCM, inoculated with single bacterial colonies and were closed with rubber stoppers. These tubes were kept under incubation at $30^{\circ} \mathrm{C}$ for 16 hours. When bacterial growth become visible in vials, injection of acetylene $\mathrm{C}_{2} \mathrm{H}_{2}(10 \%)$ was made into vials with grown bacterial culture and were kept under incubation at $30^{\circ} \mathrm{C}$ for 16 hours. Samples (triplicate) of each bacterial colony were processed for ARA. The tubes with bacterial culture but without $\mathrm{C}_{2} \mathrm{H}_{2}$ were considered as inoculated control. An additional non-inoculated (no bacterial culture) control which consists of tubes injected with acetylene $(10 \%)$ was also processed. On a Gas Chromatograph (Gasukurokogyo model 370, Tokyo, Japan) using Porapak N column (Supelco Inc., Bellefonte, Pennsylvania), for the estimation of ethylene gas produced by bacterial cultures, peak height of the samples was compared with that of standard $\left(1 \% \mathrm{C}_{2} \mathrm{H}_{4}\right)$.

Estimation of phosphate solubilization by rhizosphere bacteria: Phosphate solubilized by bacterial isolates was quantified using phosphomolybdate blue color method (Murphy and Riley, 1962) with following modifications. Single colonies of the bacterial isolates were inoculated in Luria-Bertani (LB) broth medium and grown overnight on arbitrary shaker $(150 \mathrm{rpm})$ at $30 \pm 2^{\circ} \mathrm{C}$. From these overnight grown bacterial cultures, $1.0 \mathrm{~mL}$ was inoculated to Pikovskaya broth medium (Pikovskaya, 1948) for 15 days on arbitrary shaker $(150 \mathrm{rpm})$ at $30 \pm 2^{\circ} \mathrm{C}$. Supernatant (Cell-free growth medium) was extracted by centrifugation at $6000 \mathrm{xg}$ 
for $15 \mathrm{~min}$. and $\mathrm{pH}$ of the supernatant was measured after the removal of residues through filtration. Optical density of the solutions containing bacterial culture after the development of blue color was recorded on Spectrophotometer (CamspecM350-Double Beam UV-Visible Spectrophotometer, UK) at $882 \mathrm{~nm}$ and compared with standard curve made using $\mathrm{KH}_{2} \mathrm{PO}_{4}$ 2, 4, 6, 8, 10 and $12 \mathrm{ppm}$ solutions to measure the amount of solubilized phosphate (primary and secondary orthophosphate) by the bacterial isolates.

Estimation of indol-3-acetic acid produced by wheat associated bacteria: Single bacterial colonies were developed in $\mathrm{LB}$ broth medium overnight at $30 \pm 2^{\circ} \mathrm{C}$ to estimate the concentration of bacterially produced IAA in culture medium. One $\mathrm{mL}$ of the overnight grown bacterial cultures was inoculated to $150 \mathrm{~mL}$ of growth medium (LB broth) with tryptophan $\left(100 \mathrm{mg} \mathrm{L}^{-1}\right)$ and without tryptophan (IAA biosynthesis precursor) and were grown for 15 days. By centrifugation at $6000 \mathrm{rpm}$ for $15 \mathrm{~min}$, cell-free supernatant was extracted. Acidification of the supernatant ( $\mathrm{pH} 2.8)$ was made by adding some drops of $\mathrm{HCl}(1.0 \mathrm{~N})$ and extraction of this acidified supernatant was made by adding equivalent volumes of ethyl acetate (Tien et al., 1979). The extract was dried through evaporation and suspended in ethanol $(1.0 \mathrm{~mL})$. For the quantification of bacterial culture produced IAA in vitro, pure indole-3-acetic acid (Sigma, USA) was used as standard and analysis of the samples was performed through High-performance liquid chromatography on HPLC (PerkinElmer, USA; Series 200). Ultra Violet (UV) detector and Techsphere 5-ODS C-18 column were used. The retention time and peak area of the samples was compared with that of the standard for quantification of bacterial culture produced IAA by software (Turbochrom) using an interface (Perkinelmeer, USA).

Molecular identification of selected isolates: For isolation of genomic DNA, bacterial cultures of selected isolates (LYT-1 and MWT-14) were allowed to grow for $12 \mathrm{~h}$ at $30 \pm 2^{\circ} \mathrm{C}$ in LB broth medium. Centrifugation was performed at $10,000 \mathrm{x} \mathrm{g}$ to get bacterial cell pellets and total genomic DNA extraction was then performed according to manufacturer's protocol using FastDNA SPIN Kit (MP Biomedicals, USA) and was stored at $-20^{\circ} \mathrm{C}$. The extracted DNA was used as tempelate to amplify the gene $16 S$ rRNA using primers $27 \mathrm{~F}$ (forward primer) and 1492R (reverse primer) as described earlier (Weisburg et al., 1991). PCR amplification was performed in GS0001 thermocycler (Gene Technologies, Braintree, United Kingdom) using $50 \mu \mathrm{L}$ deionized nuclease free water, $5.0 \mu \mathrm{L}$ of $2.0 \mathrm{mM}$ dNTPs, Taq buffer $5.0 \mu \mathrm{L}$ (Fermentas), $0.75 \mu \mathrm{L}$ of $5.0 \mathrm{U}^{-1}$ Taq DNA polymerase (Fermentas) and $1.5 \mu \mathrm{L}$ of each primer (forward and reverse). The extracted DNA (40 ng) was used as tempelate. Temperature conditions were also modified as initial denaturation was performed at $95^{\circ} \mathrm{C}$ for 5 minutes, 35 cycles of $95^{\circ} \mathrm{C}$ for $60 \mathrm{~s}, 55^{\circ} \mathrm{C}$ for $30 \mathrm{~s}$, and for 60 s at $72^{\circ} \mathrm{C}$. The final extension was performed at $72^{\circ} \mathrm{C}$ for 10 minutes. Purification of amplified PCR product was done by using high pure PCR Clean-up Micro Kit (Roche Applied Science, USA). Sequencing was performed commercially (Eurofins, Germany). The 16S rRNA gene sequences were analysed and compared with available sequences in the GenBank database using the NCBI BLASTn tool. Cleaned nucleotide sequences were deposited in Genbank to get accession numbers i.e. Pseudomonas sp. LYT-1 (accession no. KT933231) and Bacillus sp. MWT-14 (accession no. KT933232). Phylogenetic trees were prepared by downloading the closely related sequences from GenBank database. These sequences were aligned by CLUSTAL X and analyzed using neighbor joining method.

Inoculum preparation and field experiments: Selected bacterial isolates Pseudomonas sp. LYT-1(with nitrogen fixation and IAA synthesis ability) and Bacillus sp. MWT-14 (with phosphate solubilization activity) were grown in LB broth $(150 \mathrm{~mL})$ on arbitrary shaker $(150 \mathrm{rpm})$ at $30 \pm 2^{\circ} \mathrm{C}$ overnight. Serial dilution method was used to measure the strength of the inoculums. On LB agar medium plates, $100 \mu \mathrm{L}$ aliquots from the serial dilutions were spread and the plates were kept under incubation for $12 \mathrm{~h}$ at $30^{\circ} \mathrm{C}$. Colony forming units (CFU) was counted and inoculum of each strain was adjusted to $10^{9} \mathrm{CFU} \mathrm{mL}-1$ of saline solution. A field study to examine the effectiveness of PGPR strains Pseudomonas sp. LYT-1 and Bacillus sp. MWT-14 as sole inoculation and in combination with different levels of N-P fertilizer $(0-0,105-$ 70 and $150-100 \mathrm{~kg} \mathrm{ha}^{-1}$ ) was performed during winter season 2014-15 at two different locations (Multan and Layyah). Inoculum was mixed with sterilized filter-mud and seeds of wheat variety Galaxy-2013 were pelleted with this mixture containing filter mud and inocula $\left(10^{9} \mathrm{cfu} / \mathrm{g}\right)$. Inoculated seeds $\left(120 \mathrm{~kg} \mathrm{ha}^{-1}\right)$ were sown using hand drill. The $\mathrm{N}$ and $\mathrm{P}$ were applied on the bases of treatment. All other agronomic practices were performed equally throughout experiment. At harvest maturity (140-150 days after sowing), harvesting of the crop was done. Physico-chemical characteristics of experimental soil were determined before conducting and after the harvesting of experiment (Table 1).

Crop allometric and yield parameters: Data on plant allometric parameters such as leaf area index (LAI), leaf area duration, crop growth rate (CGR), net assimilation rate (NAR) and chlorophyll contents was recorded fortnightly started from 55 days after sowing (DAS) at tillering of the crop. A homogenous area $\left(0.5 \mathrm{~m}^{2}\right)$ from each treatment was cut randomly and leaves were separated. Total area of the separated leaves was measured by using leaf area meter (DT Area Meter, Model MK2, Delta T Devices, Cambridge, UK). The LAI was then calculated by dividing total area of the leaves to the total ground area. Thereafter, LAD, CGR and NAR were calculated by following the protocol described by Hunt (1978). Chlorophyll contents were measured using chlorophyll meter (SPAD 502, Spectrum Technologies, Inc, Aurora, IL). At maturity, yield related parameters were 
Table 1. Physico-chemical analysis of experimental soil before sowing and after harvesting at two different locations.

\begin{tabular}{lcccc}
\hline Determinant & \multicolumn{2}{c}{ Before sowing } & \multicolumn{2}{c}{ After harvesting } \\
\cline { 2 - 5 } & Layyah & Multan & Layyah & Multan \\
\hline Texture & Sandy loam & Silt loam & Sandy loam & Silt loam \\
EC $\left(\mathrm{dsm}^{-1}\right)$ & 0.52 & 2.6 & 0.57 & 2.0 \\
pH & 8.4 & 7.7 & 8.2 & 7.5 \\
Organic Matter $(\%)$ & 0.30 & 0.84 & 0.39 & 0.90 \\
P $(\mathrm{ppm})$ & 4.00 & 8.98 & 6.00 & 9.00 \\
$\mathrm{~N}(\%)$ & 0.050 & 0.080 & 0.080 & 0.095 \\
$\mathrm{~K}(\mathrm{ppm})$ & 117 & 19 & 131 & 23 \\
\hline
\end{tabular}

measured by standard procedure following by Hussain $\mathrm{et}$ al. (2016).

Statistical analysis: The collected data was analyzed using software Statistics 8.1 version. Fischer's analysis of variance technique (ANOVA) was followed during analysis, and comparison among treatments' means was performed by LSD test at 5\% probability (Steel et al., 1997). Further, graphical presentation of data was accomplished by using Microsoft Excel 2010 computer program along with \pm S.E.

Economic analysis: To evaluate the feasibility of using bacterial strains with NP levels in accelerating wheat yield economic analysis was conducted. Total expenses incurred on wheat production from sowing to harvesting were computed. The expenses included the rent of land, preparation of seedbed, sowing of crop, cost of fertilizers, cost of irrigation water, cost on bacterial strains and plant protection measures. Further, gross income was estimated by considering the current prices of the wheat grains and straw. Net profit was figured by subtracting expenses from total income (CIMMYT, 1988).

\section{RESULTS}

Isolation and screening of rhizosphere bacteria for plant beneficial traits: Among the growth media tryptophan supplemented and without tryptophan, maximum IAA production was observed in LB broth medium supplemented with tryptophan. Among the bacterial isolates, significantly
$(P<0.05)$ higher concentration $(618 \pm 11 \mathrm{mg} / \mathrm{L}$ and $2.8 \pm 0.3$ $\mathrm{mg} / \mathrm{L}$ ) of IAA was produced by the isolate Bacillus $\mathrm{sp}$. MWT14 (from Multan) in culture media supplemented with tryptophan and without tryptophan respectively. Eleven bacterial isolates were ARA positive in both NFM and CCM media. Maximum ARA $(1820 \pm 43$ and $811 \pm 21 \mathrm{n}$ mol $\mathrm{C}_{2} \mathrm{H}_{2} / \mathrm{h} / \mathrm{mg}$ protein in CCM and NFM, respectively) was observed in vial inoculated with the bacterial isolate Pseudomonas sp. LYT-1 (from Layyah). Of the total, nine bacterial isolates obtained from Pikovskaya agar medium plates were tested for P solubilization in Pikovskaya broth medium supplemented with tri-calcium phosphate (TCP). All these bacterial isolates reduced the $\mathrm{pH}$ of the medium $(\mathrm{pH} 7.0$ to $\mathrm{pH}<6)$ and solubilized phosphate $(58 \pm 4-355 \pm 14 \mu \mathrm{g} / \mathrm{mL})$ in culture medium (Table 4). Maximum amount of solubilized $\mathrm{P}$ $(355 \pm 14 \mu \mathrm{g} / \mathrm{mL})$ was obtained in Pikovskaya broth medium inoculated with bacterial isolate Bacillus sp. MWT-14.

Identification through 16S rRNA gene sequencing: 16S rRNA gene sequence analysis of the bacterial isolate LYT-1 and MWT-14 showed 98\% sequence similarity with Pseudomonas florescence strain G33 (accession no. KT767930) and Bacillus sp. LS-063 (accession no. KF870442), respectively. Phylogenetic analysis showed that among the clusters, the bacterial isolate LYT-1 formed a cluster with Pseudomonas florescence strains and the isolate MWT-14 is present in cluster containing the Bacillus thuringiensis strains (Fig. 1a,b).

Table 4. Effect of bacterial inoculation and different levels of NP fertilizer on plant height, number of productive tillers and spike length of wheat at two different locations.

\begin{tabular}{|c|c|c|c|c|c|c|c|c|c|c|c|c|c|c|c|c|c|c|}
\hline \multirow{3}{*}{$\begin{array}{l}\text { Bacterial } \\
\text { strain } \\
\text { NP levels (kg } \\
\left.\text { ha }^{-1}\right)\end{array}$} & \multicolumn{6}{|c|}{ Plant height $(\mathrm{cm})$} & \multicolumn{6}{|c|}{ Number of productive tillers $\left(\mathrm{m}^{-2}\right)$} & \multicolumn{6}{|c|}{ Spike length (cm) } \\
\hline & \multicolumn{3}{|c|}{ Multan } & \multicolumn{3}{|c|}{ Layyah } & \multicolumn{3}{|c|}{ Multan } & \multicolumn{3}{|c|}{ Layyah } & \multicolumn{3}{|c|}{ Multan } & \multicolumn{3}{|c|}{ Layyah } \\
\hline & $0-0$ & $105-70$ & $\begin{array}{c}150- \\
100\end{array}$ & $0-0$ & $105-70$ & $\begin{array}{c}150- \\
100\end{array}$ & $0-0$ & $105-70$ & $\begin{array}{c}150- \\
100\end{array}$ & $0-0$ & $105-70$ & $\begin{array}{c}150- \\
100\end{array}$ & $0-0$ & $105-70$ & $\begin{array}{c}150- \\
100\end{array}$ & $0-0$ & $105-70$ & $\begin{array}{c}150- \\
100 \\
\end{array}$ \\
\hline $\begin{array}{l}\text { Non- } \\
\text { inoculated }\end{array}$ & $63.6 \mathrm{e}$ & $90.7 b$ & $95.1 \mathrm{ab}$ & $60.6 \mathrm{e}$ & $85.4 \mathrm{~b}$ & $92.1 \mathrm{a}$ & $143.8 \mathrm{~g}$ & $\begin{array}{c}296.0 \\
d\end{array}$ & $277.3 \mathrm{e}$ & $145.8 \mathrm{f}$ & $294.0 \mathrm{~d}$ & $281.0 \mathrm{~d}$ & $7.07 \mathrm{e}$ & $9.59 \mathrm{bc}$ & $9.47 \mathrm{c}$ & $7.01 \mathrm{e}$ & $9.47 \mathrm{bc}$ & $9.34 \mathrm{c}$ \\
\hline B. subtilis & $69.9 \mathrm{~d}$ & $97.6 \mathrm{a}$ & $98.4 \mathrm{a}$ & $65.4 \mathrm{~d}$ & $93.9 \mathrm{a}$ & $93.4 \mathrm{a}$ & $158.0 \mathrm{~g}$ & $\begin{array}{l}304.0 \\
\mathrm{~cd}\end{array}$ & $316.0 \mathrm{c}$ & $160.9 \mathrm{f}$ & $\begin{array}{c}325.7 \\
\text { bc }\end{array}$ & $324.0 \mathrm{c}$ & $7.77 \mathrm{~d}$ & $9.92 \mathrm{a}-\mathrm{c}$ & $\begin{array}{c}10.12 \\
\mathrm{ab}\end{array}$ & $7.17 \mathrm{~d}$ & $9.81 \mathrm{a}-\mathrm{c}$ & $10.0 \mathrm{ab}$ \\
\hline P. aurentiaca & $77.7 \mathrm{c}$ & $95.9 \mathrm{a}$ & $96.9 \mathrm{a}$ & $75.3 \mathrm{c}$ & $91.2 \mathrm{a}$ & $90.7 \mathrm{a}$ & 176.0f & $345.3 \mathrm{~b}$ & $456.0 \mathrm{a}$ & $190.9 \mathrm{e}$ & $\begin{array}{c}342.0 \\
\mathrm{ab}\end{array}$ & $356.0 \mathrm{a}$ & $8.01 \mathrm{~d}$ & 9.98 a-c & $10.26 \mathrm{a}$ & $7.92 \mathrm{~d}$ & $9.84 \mathrm{a}-\mathrm{c}$ & $10.12 \mathrm{a}$ \\
\hline LSD at $5 \%$ & & 4.80 & & & 3.93 & & & 17.04 & & & 17.54 & & & 0.48 & & & 0.47 & \\
\hline
\end{tabular}



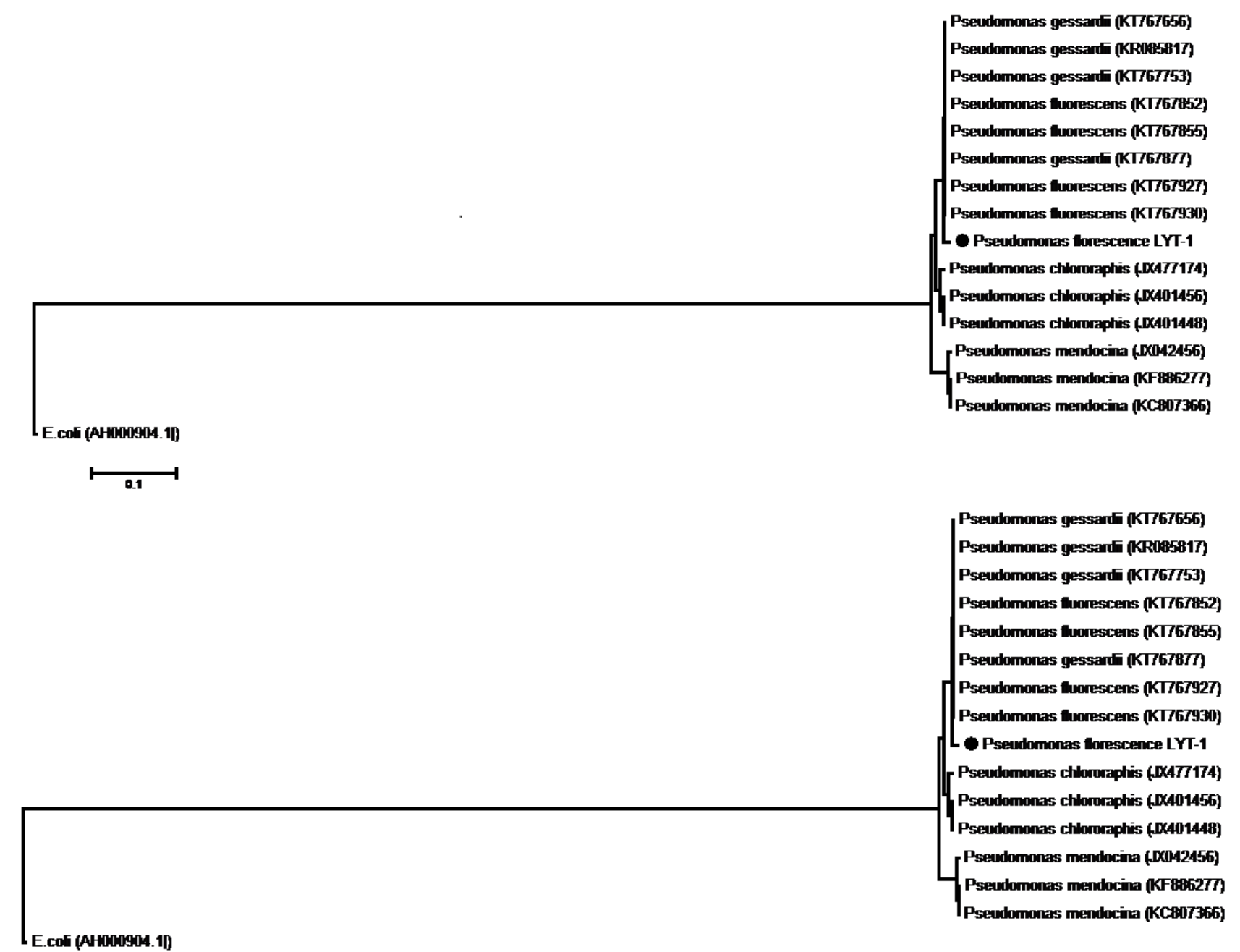

\section{1}

Figure 1. Amplified 16S rRNA gene fragments from the isolated strain Bacillus strain MWT-14 and Pseudomonas strain LYT-1 was sequenced and blast searched though NCBI database. Closely related sequences were downloaded and aligned using CLUSTAL $X$. These sequences were analyzed using neighbor-joining method. The bootstrap replicates (BS) values of $50 \%$ or greater represent well supported nodes and thus only those were retained. $E$. coli (AH000904) was taken as out-group.

Effect of PGPR inoculation on growth and productivity of wheat: In field experiments, interactive effect between bacterial strains and NP levels was significant $(P<0.05)$ on chlorophyll contents, leaf area, leaf area index (LAI), leaf area duration (LAD), crop growth rate (CGR) and net assimilation rate (NAR) of wheat. Both the bacterial strains, specifically Pseudomonas sp. LYT-1, increased chlorophyll contents of wheat at all fertilizer levels over non-inoculated control treatments at both the experimental sites (Fig. 2a,b). However, results were non-significant at 90 DAS with NP rate of $150-100 \mathrm{~kg} \mathrm{ha}^{-1}$ with respect to bacterial strains. Similarly, LAI (Fig. 3a,b) and LAD (Fig. 4a,b) was significantly higher $(P<0.05)$ in treatments inoculated with
Pseudomonas sp. LYT-1 at all fertilizer levels as compared to their respective non-inoculated control during the entire growth period at both experimental locations. However, LAI and LAD was significantly $(P<0.0 .5)$ higher only at 60 DAS in treatment inoculated with Bacillus sp. MWT-14 as compared to non-inoculated control and the treatment inoculated with Pseudomonas sp. LYT-1 with all fertilizer levels. Inoculation of wheat with Bacillus sp. MWT-14 improved CGR at 55-70 DAS and 75-80 DAS in combination with all fertilizer doses but at 40-55 DAS, CGR was higher in the treatments inoculated with Pseudomonas sp. LYT-1 at both the experimental sites (Fig. 5a,b). Application of NP fertilizer at the rate of $150-100 \mathrm{~kg} \mathrm{ha}^{-1}$ along with bacterial 
inoculation observed higher NAR at both locations (Fig. 6a,b) over non-inoculated control.

(2a)

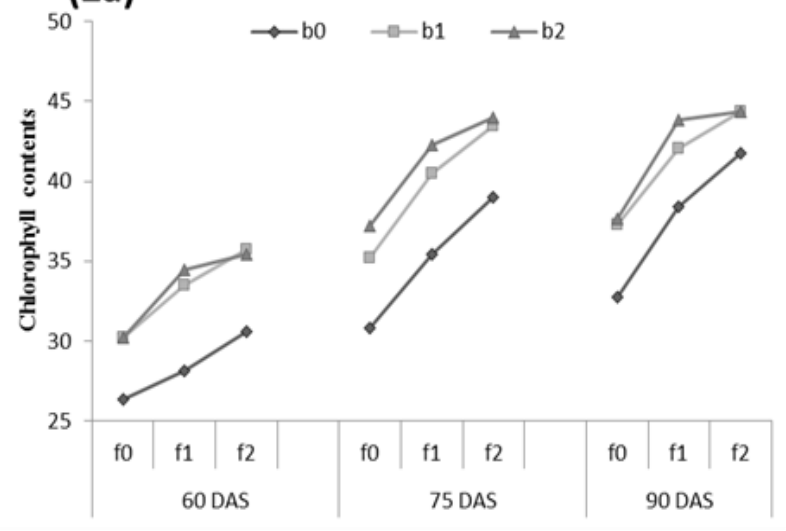

(2b)

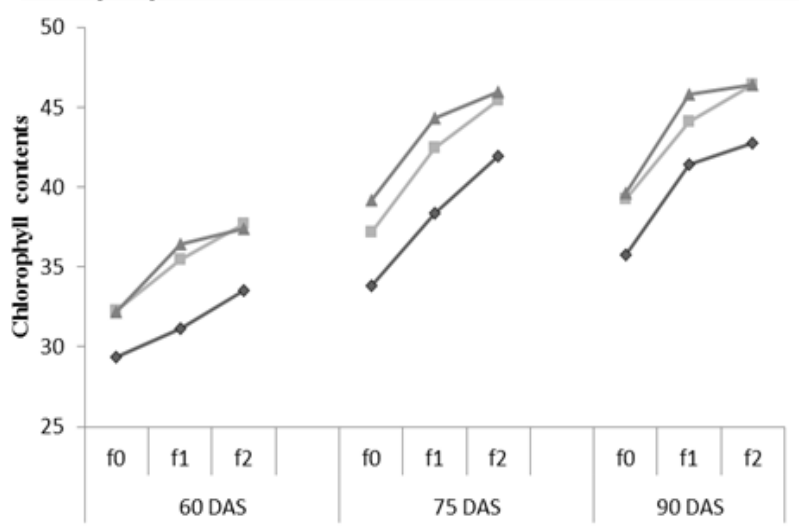

Figure 2. Chlorophyll contents of wheat as influenced by PGPR inoculation and different levels of NP fertilizer at two different locations; 2a) Multan, 2b) Layyah.

(3a)

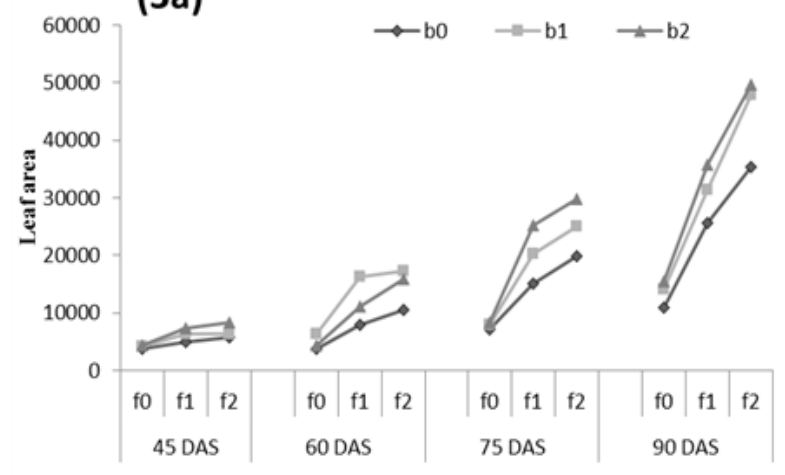

(3b)

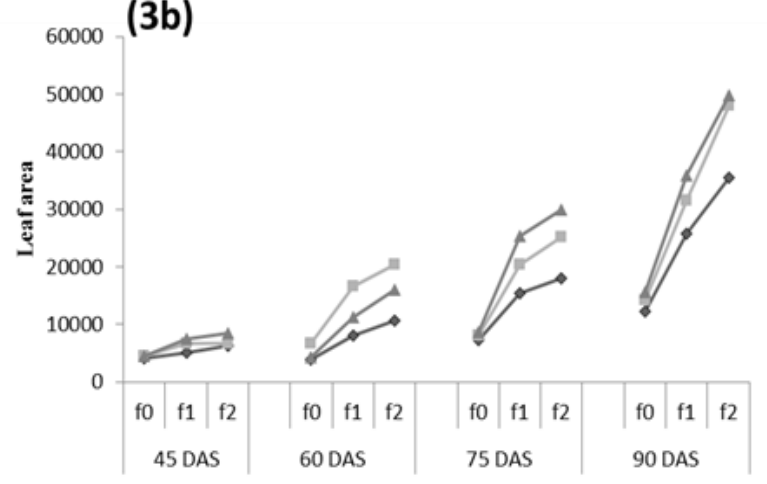

Figure 3. Leaf area of wheat as influenced by PGPR inoculation and different levels of NP fertilizer at two different locations; 3a) Multan, 3b) Layyah.
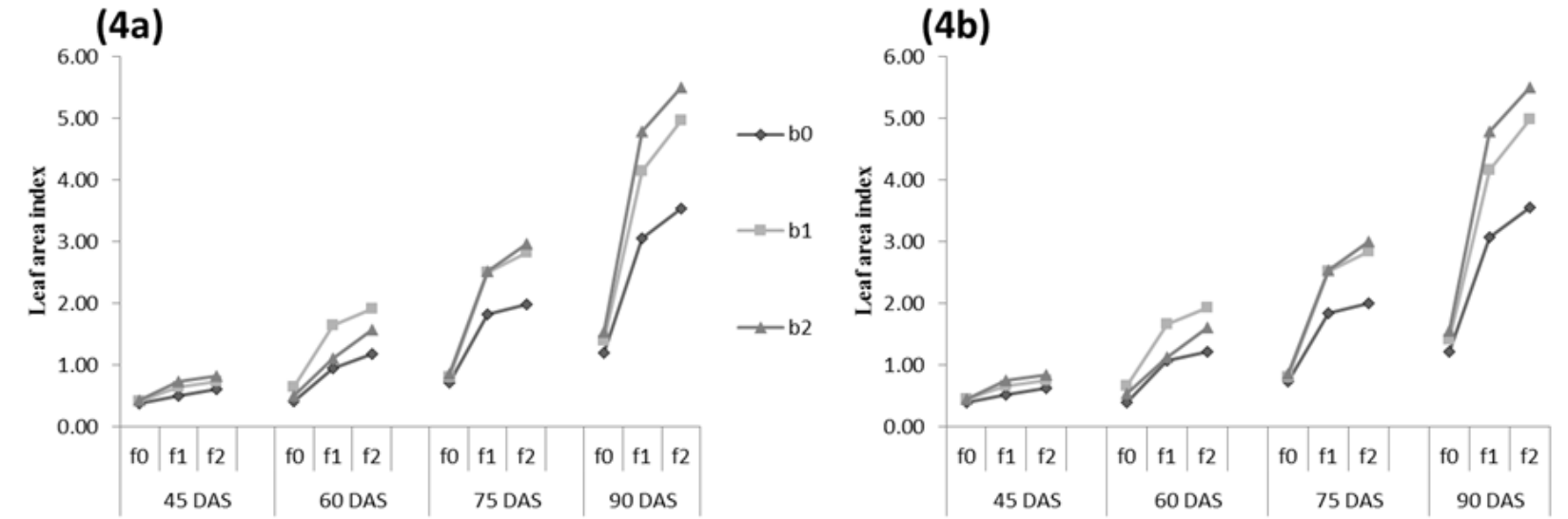

Figure 4. Leaf area index of wheat as influenced by PGPR inoculation and different levels of NP fertilizer at two different locations; 4a) Multan, 4b) Layyah. 

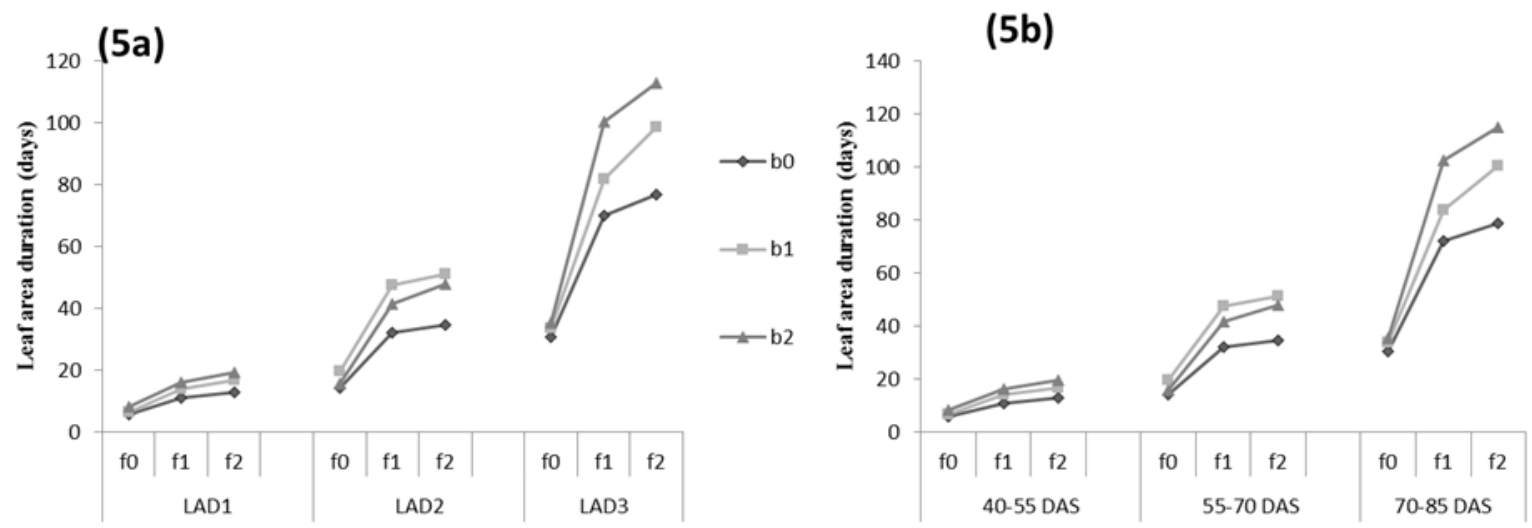

Figure 5. Leaf area duration of wheat as influenced by PGPR inoculation and different levels of NP fertilizer at two different locations; 5a) Multan, 5b) Layyah.
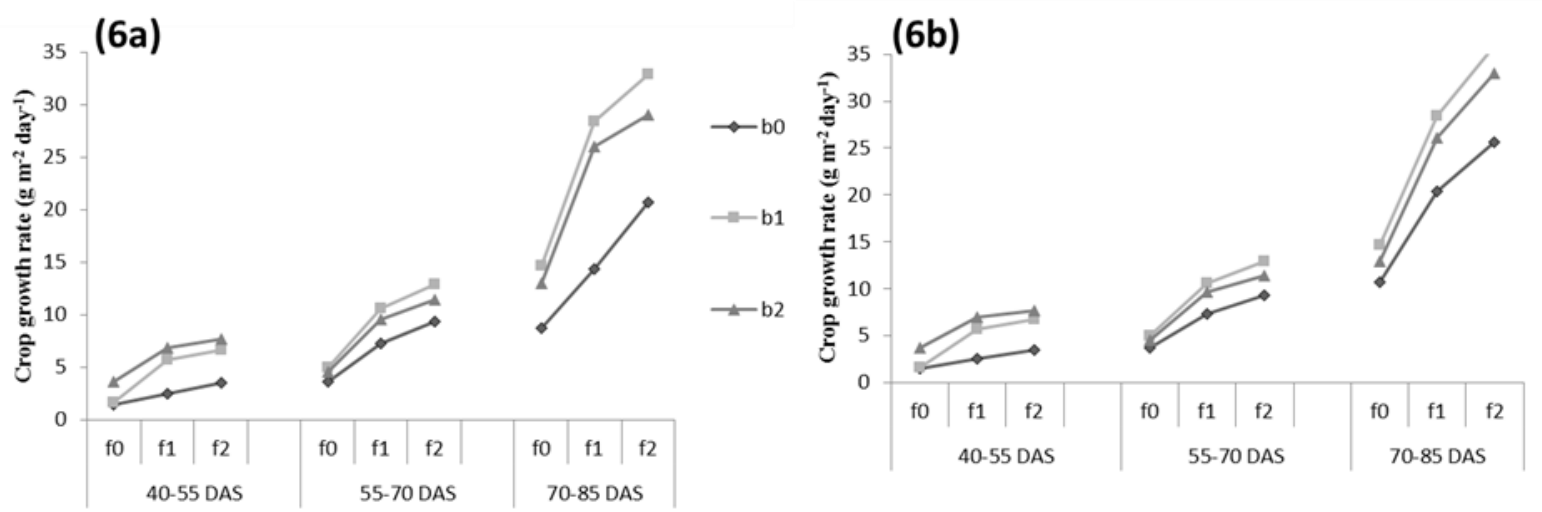

Figure 6. Crop growth rate of wheat as influenced by PGPR inoculation and different levels of NP fertilizer at two different locations; 6a) Multan, 6b) Layyah.
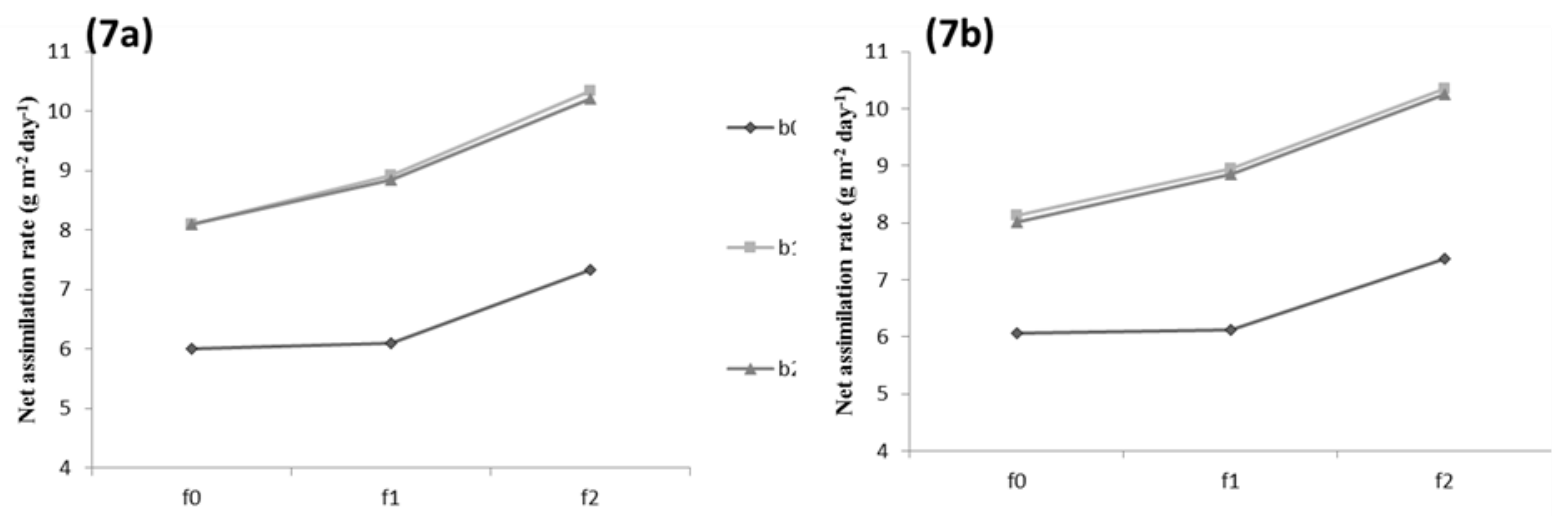

Figure 7. Net assimilation rate of wheat as influenced by PGPR inoculation and different levels of NP fertilizer at two different locations; 6a) Multan, 6b) Layyah.

Interactive effect between bacterial strains and NP levels was significant on plant height, population of productive tillers and spike length of wheat at both experimental locations (Table 4). Both bacterial strains, Pseudomonas sp. LYT-1 in particular, improved plant height, population of productive tillers and spike length of wheat at all fertilizer levels but the effect was more outstanding at higher level of NP (Table 4). Non-inoculated control treatment with all $\mathrm{N}-\mathrm{P}_{2} \mathrm{O}_{5}$ fertilizer levels resulted in significantly lower plant height, number of productive tillers and spike length at both the locations (Table 4). Number of spikelets per spike, number of grains per spike and 1000 -grain weight was significantly $(P<0.05)$ affected 
due to interactive outcome of different NP fertilizer levels and bacterial strain inoculation (Table 5). Both the bacterial strains, Pseudomonas sp. LYT-1 specifically, improved number of spikelets per spike and number of grains per spike of wheat at all NP fertilizer levels but the impact was more outstanding at higher levels of NP fertilizer (Table 5). Interestingly, the 1000-grain weight was obtained maximum in the treatment where the bacterial strain Bacillus sp. MWT14 was inoculated along with all levels of NP fertilizer. However, the 1000-grain weight was recorded maximum with MWT-14 inoculation along with higher levels of NP fertilizer at both the experimental sites (Table 5). Minimum numbers of spikelets per spike, number of grains per spike and 1000grain weight were obtained in non-inoculated control treatment with application of $\mathrm{N}_{-} \mathrm{P}_{2} \mathrm{O}_{5}$ at $0-0 \mathrm{~kg} \mathrm{ha}^{-1}$ at both experimental locations (Table 5).

Interaction between the different NP fertilizer levels and bacterial strains inoculation showed significant effect on straw and grain yield of wheat at both locations (Table 6).
Straw yield was improved with increased NP fertilizer levels, particularly with higher fertilizer dose. Both the strains, Pseudomonas sp. LYT-1 in particular, improved the straw yield of wheat at all fertilizer levels at both the experimental sites (Table 6). However, the impact was more distinct with higher NP fertilizer levels at both the experimental locations. Grain yield was increased due to Bacillus sp. MWT-14 inoculation with all NP fertilizer levels at both the experimental sites (Table 6). Minimum straw yield and grain yield was obtained in non-inoculated control treatments with zero application of NP fertilizer.

Interactive effect between bacterial strains and NP fertilizer levels was significant on biological yield and harvest index of wheat at both experimental locations (Table 7). Both the bacterial strains, Pseudomonas sp. LYT-1 in particular, improved biological yield of wheat at all fertilizer levels but the effect was more prominent at higher level of NP (Table 7). Inoculation of bacterial strain Bacillus sp. MWT-14 increased the harvest index $(\%)$ over all other treatments at

Table 5. Effect of bacterial inoculation and different levels of NP fertilizer on number of spikelets per spike, number of grains per spike and 1000 grain weight of wheat at two different locations.

\begin{tabular}{|c|c|c|c|c|c|c|c|c|c|c|c|c|c|c|c|c|c|c|}
\hline \multirow{3}{*}{$\begin{array}{l}\begin{array}{l}\text { Bacterial } \\
\text { strain }\end{array} \\
\begin{array}{l}\text { NP levels (kg } \\
\left.\text { ha }^{-1}\right)\end{array} \\
\end{array}$} & \multicolumn{6}{|c|}{ Number of spikelets per spike } & \multicolumn{6}{|c|}{ Number of grains per spike } & \multicolumn{6}{|c|}{1000 grain weight $(\mathrm{g})$} \\
\hline & \multicolumn{3}{|c|}{ Multan } & \multicolumn{3}{|c|}{ Layyah } & \multicolumn{3}{|c|}{ Multan } & \multicolumn{3}{|c|}{ Layyah } & \multicolumn{3}{|c|}{ Multan } & \multicolumn{3}{|c|}{ Layyah } \\
\hline & $0-0$ & $105-70$ & $\begin{array}{l}150- \\
100 \\
\end{array}$ & $0-0$ & $105-70$ & $\begin{array}{c}150- \\
100 \\
\end{array}$ & $0-0$ & $105-70$ & $\begin{array}{c}150- \\
100 \\
\end{array}$ & $0-0$ & $105-70$ & $\begin{array}{c}150- \\
100 \\
\end{array}$ & $0-0$ & $105-70$ & $\begin{array}{c}150- \\
100 \\
\end{array}$ & $0-0$ & $105-70$ & $\begin{array}{c}150- \\
100\end{array}$ \\
\hline $\begin{array}{l}\text { Non- } \\
\text { inoculated }\end{array}$ & $12.9 \mathrm{~d}$ & $15.9 \mathrm{~b}$ & $15.9 \mathrm{~b}$ & $11.11 \mathrm{c}$ & $13.0 \mathrm{ab}$ & $\begin{array}{c}13.02 \mathrm{a} \\
\mathrm{b}\end{array}$ & $21.1 \mathrm{~g}$ & $27.9 \mathrm{de}$ & $29.1 \mathrm{~cd}$ & $19.1 \mathrm{~b}$ & $19.60 \mathrm{~b}$ & $19.9 \mathrm{~b}$ & $39.9 \mathrm{c}$ & $\begin{array}{c}42.5 \mathrm{a}- \\
\mathrm{c}\end{array}$ & $43.3 \mathrm{ab}$ & $37.6 \mathrm{~d}$ & $\begin{array}{c}39.03 \\
\mathrm{~cd}\end{array}$ & $\begin{array}{c}39.5 \text { b- } \\
\text { d }\end{array}$ \\
\hline B. subtilis & $14.2 \mathrm{c}$ & $16.5 \mathrm{ab}$ & $17.2 \mathrm{a}$ & $13.1 \mathrm{a}$ & $13.4 \mathrm{a}$ & $14.1 \mathrm{a}$ & $23.1 \mathrm{fg}$ & $\begin{array}{c}30.1 \mathrm{~b}- \\
\mathrm{d}\end{array}$ & $32.3 \mathrm{~b}$ & $19.8 \mathrm{~b}$ & $23.70 \mathrm{a}$ & $24.3 \mathrm{a}$ & $43.8 \mathrm{ab}$ & $44.8 \mathrm{a}$ & $45.3 \mathrm{a}$ & $38.4 \mathrm{~d}$ & $41.6 \mathrm{a}$ & $41.1 \mathrm{ab}$ \\
\hline P. aurentiaca & $14.6 \mathrm{c}$ & $16.7 \mathrm{ab}$ & $17.2 \mathrm{a}$ & $11.2 \mathrm{bc}$ & $13.3 \mathrm{a}$ & $13.7 \mathrm{a}$ & 25.1ef & $31.3 \mathrm{bc}$ & $37.1 \mathrm{a}$ & $20.2 \mathrm{~b}$ & $23.5 \mathrm{a}$ & $25.3 \mathrm{a}$ & $41.3 \mathrm{bc}$ & $43.4 \mathrm{ab}$ & $43.8 \mathrm{ab}$ & $38.2 \mathrm{~d}$ & $41.7 \mathrm{a}$ & $\begin{array}{c}40.5 \text { a- } \\
\quad c\end{array}$ \\
\hline LSD at $5 \%$ & & 0.93 & & & 1.88 & & & 2.81 & & & 1.87 & & & 2.99 & & & 2.02 & \\
\hline
\end{tabular}

For recording 1000-grain weight, three random samples each of 1000 grains were taken from seed lot of every plot and observed weights (g) were averaged.

Each value in the Table 6 is the mean of 3 values.

Table 6. Effect of bacterial inoculation and different levels of NP fertilizer on straw yield and grain yield of wheat at two different locations.

\begin{tabular}{|c|c|c|c|c|c|c|c|c|c|c|c|c|}
\hline \multirow{3}{*}{$\begin{array}{l}\text { Bacterial strain } \\
\text { NP levels }\left(\mathrm{kg} \mathrm{ha}^{-1}\right) \\
\end{array}$} & \multicolumn{6}{|c|}{ Straw yield $\left(\mathrm{t} \mathrm{ha}^{-1}\right)$} & \multicolumn{6}{|c|}{ Grain yield $\left(\mathrm{t} \mathrm{ha}^{-1}\right)$} \\
\hline & \multicolumn{3}{|c|}{ Multan } & \multicolumn{3}{|c|}{ Layyah } & \multicolumn{3}{|c|}{ Multan } & \multicolumn{3}{|c|}{ Layyah } \\
\hline & $0-0$ & $105-70$ & $150-100$ & $0-0$ & $105-70$ & $150-100$ & $0-0$ & $105-70$ & $150-100$ & $0-0$ & $105-70$ & $150-100$ \\
\hline Non-inoculated & $2.05 \mathrm{e}$ & $4.47 \mathrm{~d}$ & $5.42 \mathrm{c}$ & $1.85 \mathrm{~d}$ & $3.10 \mathrm{c}$ & $3.56 \mathrm{~b}$ & $2.40 \mathrm{f}$ & $3.50 \mathrm{~d}$ & $4.00 \mathrm{bc}$ & $2.21 \mathrm{e}$ & $3.50 \mathrm{c}$ & $4.00 \mathrm{~b}$ \\
\hline B. subtilis & $2.15 \mathrm{e}$ & $6.10 \mathrm{~b}$ & $5.52 \mathrm{c}$ & $1.90 \mathrm{~d}$ & $3.57 \mathrm{~b}$ & $4.30 \mathrm{a}$ & $2.79 \mathrm{e}$ & $3.93 \mathrm{bc}$ & $4.40 \mathrm{a}$ & $2.59 \mathrm{~d}$ & $4.03 \mathrm{~b}$ & $4.34 \mathrm{a}$ \\
\hline P. aurentiaca & $2.37 \mathrm{e}$ & $6.25 \mathrm{~b}$ & $7.43 \mathrm{a}$ & $1.89 \mathrm{~d}$ & $3.64 \mathrm{~b}$ & $4.35 \mathrm{a}$ & $2.53 \mathrm{ef}$ & $3.87 \mathrm{c}$ & $4.20 \mathrm{~b}$ & $2.40 \mathrm{~d}$ & $4.00 \mathrm{~b}$ & $4.20 \mathrm{a}$ \\
\hline LSD at $5 \%$ & & 0.57 & & & 0.25 & & & 0.26 & & & 0.14 & \\
\hline
\end{tabular}

To record biological yield, each plot was harvested manually, sun dried for a week, tied into bundles and weighed for getting biological yield. After recording biological yield, the bundles were threshed manually and the grains were weighed to record grain yield. Straw yield was recorded by weighing the left over straw. The yields (biological, grain and straw) from the harvested areas were converted into kg ha-1 by unitary method. Each value in the Table 6 is the mean of 3 values.

Table 7. Effect of bacterial inoculation and different levels of NP fertilizer on Biological yield and Harvest index of wheat at two different locations.

\begin{tabular}{|c|c|c|c|c|c|c|c|c|c|c|c|c|}
\hline \multirow{3}{*}{$\begin{array}{l}\text { Bacterial strain } \\
\text { NP levels }\left(\mathrm{kg} \mathrm{ha}^{-1}\right)\end{array}$} & \multicolumn{6}{|c|}{ Biological yield $\left(\mathrm{t} \mathrm{ha}^{-1}\right)$} & \multicolumn{6}{|c|}{ Harvest index (\%) } \\
\hline & \multicolumn{3}{|c|}{ Multan } & \multicolumn{3}{|c|}{ Layyah } & \multicolumn{3}{|c|}{ Multan } & \multicolumn{3}{|c|}{ Layyah } \\
\hline & $0-0$ & $105-70$ & $150-100$ & $0-0$ & $105-70$ & $150-100$ & $0-0$ & $105-70$ & $150-100$ & $0-0$ & $105-70$ & $150-100$ \\
\hline Non-inoculated & $4.45 \mathrm{e}$ & $7.97 \mathrm{~d}$ & $9.42 \mathrm{c}$ & $4.06 \mathrm{e}$ & $7.10 \mathrm{c}$ & $7.56 \mathrm{~b}$ & $53.9 \mathrm{ab}$ & $43.9 \mathrm{c}$ & $42.5 \mathrm{c}$ & $54.4 \mathrm{ab}$ & $56.3 \mathrm{a}$ & $52.9 \mathrm{~b}$ \\
\hline B. subtilis & $4.94 \mathrm{e}$ & $10.03 b$ & $9.92 \mathrm{bc}$ & $4.49 \mathrm{~d}$ & $7.59 \mathrm{~b}$ & $8.64 \mathrm{a}$ & $56.5 \mathrm{a}$ & $39.2 \mathrm{~d}$ & $44.4 \mathrm{c}$ & $57.7 \mathrm{a}$ & $53.1 \mathrm{a}$ & $56.8 \mathrm{a}$ \\
\hline $\begin{array}{l}\text { P. aurentiaca } \\
\text { LSD at } 5 \%\end{array}$ & $4.90 \mathrm{e}$ & $\begin{array}{r}10.12 b \\
0.61\end{array}$ & $11.53 \mathrm{a}$ & $4.29 \mathrm{~d}$ & $\begin{array}{c}7.57 \mathrm{~b} \\
0.24\end{array}$ & $8.55 \mathrm{a}$ & $51.6 \mathrm{~b}$ & $\begin{array}{c}38.2 \mathrm{~d} \\
3.98\end{array}$ & $36.1 \mathrm{e}$ & $55.9 \mathrm{a}$ & $\begin{array}{c}52.0 \mathrm{~b} \\
3.40\end{array}$ & $49.1 \mathrm{c}$ \\
\hline
\end{tabular}

Harvest index (HI) was taken as ratio of grain yield to biological yield expressed in percentage. Each value in the Table 7 is mean of three values. 
both the experimental sites. Non-inoculated control treatment with all $\mathrm{N}-\mathrm{P}_{2} \mathrm{O}_{5}$ fertilizer levels resulted in significantly lesser biological yield and harvest index at both the locations (Table 7).

\section{DISCUSSION}

Domination of crop rhizosphere by variety of bacteria enforced the researchers to isolate the bacteria exhibiting plant growth promoting traits. Bacterial growth become visible after $48 \mathrm{~h}$ as a veil like pellicle in NFM growth medium inoculated with roots and attached soil. This pellicle formation in NFM semisolid was initially considered a characteristic of Azospirillum, which finds suitable oxygen concentration just below the surface due to its microaerophilic nature (Tarrand et al., 1978). However, other studies (Gupta et al., 2014; Haahtela et al., 1981) proved the isolation of other microaerophilic bacteria including species with nitrogen fixing activities from nitrogen-free semisolid media. Isolation of diazotrophs from the rhizosphere of various crops using nitrogen-free semisolid media have also been reported (Malik et al., 1997; Mehnaz, 2015; Mehnaz et al., 2001; Mirza et al., 2014; Rennie et al., 1982.; Tahir et al., 2013). Among the 13 isolates obtained from Pikovskaya agar medium plates, phosphate solubilization was observed in 8 bacterial isolates. Pikovskaya medium contain insoluble $\mathrm{P}$ in the form of tricalcium phosphate (TCP) and is commonly used medium for the isolation of P-solubilizing bacteria (Perez et al., 2007; Pikovskaya, 1948; Shahid et al., 2014; Tahir et al., 2013). Among all bacterial isolates, the isolate Pseudomonas sp. LYT-1 from Layyah region showed significantly higher $(P<0.05) \quad$ ARA activity $(1820 \pm 43$ and $811 \pm 21 \mathrm{n}$ $\mathrm{molC}_{2} \mathrm{H}_{4} / \mathrm{h} / \mathrm{mg}$ protein in CCM and NFM, respectively), this strain also produced higher concentration $(521 \pm 10 \mu \mathrm{g} / \mathrm{mL})$ of IAA in tryptophan supplemented growth medium (Table 2). Association of strains belongs to genus Pseudomonas with grasses and $\mathrm{N}$ fixing ability of the strains (Bahulikar et al., 2014; Baldani et al., 2014) has been reported. Previous studies have proved the Pseudomonas as IAA producing bacteria. The strain Bacillus sp. MWT-14 from Multan region produced significantly higher amount of IAA in tryptophan supplemented medium (Table 2). The same strain also

Table 2. Acetylene reduction activity and indole-3- acetic acid production of the associated bacteria with the rhizosphere of wheat grown on two different agro-climatic conditions of southern Punjab.

\begin{tabular}{|c|c|c|c|c|}
\hline \multirow[t]{2}{*}{ Bacterial isolates } & \multicolumn{2}{|c|}{ IAA production $(\mathrm{mg} / \mathrm{L})$} & \multicolumn{2}{|c|}{ ARA (n mol C2H4/h/mg protein) } \\
\hline & Without tryptophan & With tryptophan & NFM & CCM \\
\hline LYT-1 & $2.5 \pm 0.2$ & $521 \pm 10$ & $811 \pm 21$ & $1820 \pm 43$ \\
\hline LYT-2 & $0.4 \pm 0.1$ & $150 \pm 6$ & ND & ND \\
\hline LYT-3 & $1.2 \pm 0.2$ & $110 \pm 11$ & $11 \pm 1.0$ & $105 \pm 10$ \\
\hline LYT-4 & ND & ND & ND & ND \\
\hline LYT-5 & $1.5 \pm 0.2$ & $418 \pm 17$ & $12 \pm 1$ & $125 \pm 12$ \\
\hline LYT-6 & $2.0 \pm 0.1$ & $492 \pm 5$ & $5 \pm 0.2$ & $72 \pm 6$ \\
\hline LYT-7 & $1.8 \pm 0.1$ & $50 \pm 7$ & ND & ND \\
\hline LYT-8 & $2.3 \pm 0.1$ & $21 \pm 1.5$ & ND & ND \\
\hline MWT-9 & $0.8 \pm 0.1$ & $18 \pm 1.5$ & $10 \pm 1.5$ & $62 \pm 4$ \\
\hline MWT-10 & $0.5 \pm 0.1$ & $12 \pm 1.0$ & ND & ND \\
\hline MWT-11 & $0.8 \pm 0.2$ & $20 \pm 21$ & ND & ND \\
\hline MWT-12 & $2.0 \pm 0.2$ & $55 \pm 8$ & $21 \pm 1.0$ & $132 \pm 8$ \\
\hline MWT-13 & $2.0 \pm 0.1$ & $115 \pm 8$ & $24 \pm 1.0$ & $93 \pm 7$ \\
\hline MWT-14 & $2.8 \pm 0.3$ & $618 \pm 11$ & ND & ND \\
\hline MWT-15 & $1.9 \pm 0.2$ & $21 \pm 2$ & $3.0 \pm 0.5$ & $51 \pm 2$ \\
\hline MWT-16 & $1.5 \pm 0.2$ & $16 \pm 4$ & $3.0 \pm 0.2$ & $35 \pm 3$ \\
\hline MWT-17 & $1.2 \pm 0.1$ & $32 \pm 4$ & $8 \pm 0.8$ & $85 \pm 3$ \\
\hline MWT-18 & $1.3 \pm 0.1$ & $12 \pm 1.2$ & $21 \pm 2$ & $63 \pm 4$ \\
\hline MWT-19 & $1.8 \pm 0.3$ & $125 \pm 12$ & ND & ND \\
\hline MWT-20 & $2.8 \pm 0.4$ & $281 \pm 12$ & ND & ND \\
\hline MWT-21 & ND & ND & ND & ND \\
\hline MWT-22 & ND & ND & ND & ND \\
\hline
\end{tabular}

Bacterial cultures were grown in semi-solid NFM and CCM media for estimation of nitrogen fixation. After $48 \mathrm{~h}$, acetylene $(10 \%)$ was injected and samples were again incubated at $30^{\circ} \mathrm{C}$ for 16 hours. ARA activity was observed through gas chromatography; For the estimation of IAA produced, bacterial cultures were grown in medium supplemented with and without tryptophan for two weeks. Supernatant was extracted, acidified with $\mathrm{HCl}$ and analyzed on HPLC ; ND = not determined; Each value is the mean of three replicates \pm Standard deviation. 
reduced $\mathrm{pH}$ from 7.0 to $4.8 \pm 0.2$ of the Pikovskaya broth medium supplemented with TCP (Table 3 ) and solubilised maximum amount of phosphorous $(355 \pm 14 \mu \mathrm{g} / \mathrm{mL})$.

Table 3. Phosphate solubilization and $\mathrm{pH}$ of the broth medium supplemented with tricalcium phosphate by the associated bacterial isolates with the rhizosphere of wheat grown on two different agro-climatic conditions of southern Punjab.

\begin{tabular}{lcc}
\hline $\begin{array}{l}\text { Bacterial } \\
\text { isolates }\end{array}$ & $\begin{array}{c}\mathrm{pH} \text { of the } \\
\text { medium }\end{array}$ & $\begin{array}{c}\text { P-solubilization } \\
(\mu \mathrm{g} / \mathrm{mL})\end{array}$ \\
\hline LYT-1 & $6.8 \pm 0.2$ & $\mathrm{ND}$ \\
LYT-2 & $5.2 \pm 0.1$ & $58 \pm 4$ \\
LYT-3 & $6.9 \pm 0.2$ & $\mathrm{ND}$ \\
LYT-4 & $5.8 \pm 0.2$ & $62 \pm 3$ \\
LYT-5 & $7.0 \pm 0.1$ & $\mathrm{ND}$ \\
LYT-6 & $7.0 \pm 0.2$ & $\mathrm{ND}$ \\
LYT-7 & $5.0 \pm 0.2$ & $183 \pm 5$ \\
LYT-8 & $5.1 \pm 0.2$ & $151 \pm 3$ \\
MWT-9 & $6.8 \pm 0.2$ & $\mathrm{ND}$ \\
MWT-10 & $5.5 \pm 0.1$ & $136 \pm 3$ \\
MWT-11 & $5.4 \pm 0.1$ & $140 \pm 6$ \\
MWT-12 & $6.9 \pm 0.2$ & $\mathrm{ND}$ \\
MWT-13 & $7.0 \pm 0.1$ & $\mathrm{ND}$ \\
MWT-14 & $4.8 \pm 0.2$ & $355 \pm 14$ \\
MWT-15 & $7.0 \pm 0.1$ & $\mathrm{ND}$ \\
MWT-16 & $6.9 \pm 0.1$ & $\mathrm{ND}$ \\
MWT-17 & $6.9 \pm 0.1$ & $\mathrm{ND}$ \\
MWT-18 & $7.0 \pm 0.1$ & $\mathrm{ND}$ \\
MWT-19 & $5.7 \pm 0.2$ & $110 \pm 7$ \\
MWT-20 & $5.6 \pm 0.2$ & $122 \pm 2$ \\
\hline
\end{tabular}

Bacterial cultures were grown in Pikovskaya broth medium for 15 days. Supernatant was extracted by centrifugation and phosphate solubilization was determined on spectrophotometer using molybdate blue color method; $\mathrm{ND}=$ not determined; Each value is the mean of three values; \pm Standard deviation.

Association and isolation of phosphate solubilising Bacillus strains from the rhizosphere of various crops like wheat, rice, sugarcane and maize has been frequently reported (Tahir et al., 2015; Tahir et al., 2013). Two bacterial strains Pseudomonas sp. LYT-1 (with highest ARA activity) and Bacillus sp. MWT-14 (possessed highest P-solubilization and IAA production) were selected to investigate their PGPR potential for wheat under field conditions at two different locations in combination with different levels of NP fertilizer. Inoculation of wheat with PGPR either as sole application or in combination with all levels of NP fertilizer increased the chlorophyll contents, LAI, LAD, CGR and NAR during the entire crop growth period at both locations (Fig. 2a-6b). Among the bacterial strains, the strain Bacillus sp. MWT-14 performed extraordinary best in improving growth parameters at 60 DAS while the performance of the strain Pseudomonas sp. LYT-1 was better at 45, 75 and 90 DAS. The reason for this may be the soil factors like temperature, moisture, aeration, root exudates nature and indigenous bacterial population at that specific plant growth stage was more suitable for the growth, survival and activity of the Pseudomonas strain. Previous studies have reported that the population, diversity, survival and activity of bacteria is affected due to nature of root exudates and indigenous rhizosphere bacteria (Shridhar, 2012; Tahir et al., 2015; Walker et al., 2003).

Both the bacterial strains, Pseudomonas sp. LYT-1 in particular, improved plant height, number of productive tillers, spike length, grains count, straw yield and biological yield of wheat at all fertilizer levels but the effect was more prominent at higher level of NP. This might be due to the fact that the strain Pseudomonas sp. LYT-1 had higher ARA activity; so its inoculation as bio-inoculant along with chemical fertilizer might improve $\mathrm{N}$ and $\mathrm{P}$ availability to the plants. This has been proved that $\mathrm{N}$, being macro-nutrient, plays an important role in formation of plant cell proteins and other essential bio-molecules and improves the plant vegetative as well as reproductive growth (Shridhar, 2012). In previous studies it has been reported that inoculation of $\mathrm{N}$ fixing bacteria increased the uptake of $\mathrm{N}$ and improved growth of wheat (Abbasdokht and Gholami 2010; Baldani et al., 2014).

Grain yield was surprisingly higher due to interaction between different NP levels and inoculation of Bacillus sp. MWT-14. This strain solubilized more concentration of insoluble phosphate and produced IAA in vitro. Inoculation of Bacillus as bio-inoculant might have resulted in increased root area, $\mathrm{P}$ availability and uptake of other nutrients which resulted in accumulation of more food in grain and ultimately the 1000-grain weight and grain yield was increased in Bacillus inoculated plants. It has been reported previously that inoculation of phosphate solubilizing bacteria improved the $\mathrm{P}$ uptake by solubilizing insoluble $\mathrm{P}$ and increased the growth and yield of wheat and other crops (Shahid et al., 2012; Tahir et al., 2013; Gupta et al., 2014; Panhwar et al., 2014).

The data about economic analysis (Tables 8,9 ) revealed that there was an overall increase in the net benefits from inoculated treatments (with $150-100 \mathrm{~kg} \mathrm{ha}^{-1} \mathrm{~N}-\mathrm{P}$ as well as $105-70 \mathrm{~kg} \mathrm{ha}^{-1} \mathrm{~N}-\mathrm{P}$ ) as compared to both the non-inoculated control treatments at both the experimental sites. Among different treatments the highest net benefits (269.91 and 251.45 US\$ ha ${ }^{-1}$ at Layyah and Multan, respectively) were obtained from the treatment where PGPR strain Bacillus sp. MWT-14 was used as inoculum along with $105-70 \mathrm{~kg}$ NP ha ${ }^{1}$. The same strain generated highest net income of 262.97 US\$ ha ${ }^{-1}$ at Multan and 240.01 US\$ ha $a^{-1}$ at Layyah with NP fertilizer dose of $150-100 \mathrm{~kg} \mathrm{ha}^{-1}$. The new innovated technology adapted on the bases their economic feasibility for the farmer (Shah et al., 2013) Minimum net income was produced from non-inoculated treatment with zero NP 
Plant growth promoting rhizobacteria

Table 8. Variable and fixed cost for economic analysis, Multan.

\begin{tabular}{|c|c|c|c|c|c|c|c|c|c|c|}
\hline Treatment & $\mathbf{T}_{1}$ & $\mathbf{T}_{2}$ & $\mathbf{T}_{3}$ & $\mathbf{T}_{4}$ & $\mathbf{T}_{5}$ & $\mathbf{T}_{6}$ & $\mathbf{T}_{7}$ & T8 & T9 & Remarks \\
\hline Grain yield & 2.4 & 2.79 & 2.53 & 3.5 & 3.93 & 3.87 & 4 & 4.4 & 4.2 & t.ha ${ }^{-1}$ \\
\hline $\begin{array}{l}\text { Adjusted grain } \\
\text { yield }\end{array}$ & 2.16 & 2.51 & 2.28 & 3.15 & 3.54 & 3.48 & 3.6 & 3.96 & 3.78 & $\begin{array}{l}10 \% \text { less than actual to } \\
\text { bring at farmer's level }\end{array}$ \\
\hline Gross benefit (a) & 636.12 & 739.48 & 670.58 & 927.68 & 1041.65 & 1025.74 & 1060.2 & 1166.22 & 1113.21 & 294.5 US\$/ton \\
\hline Straw yield & 2.05 & 2.15 & 2.37 & 3.10 & 6.1 & 6.25 & 5.42 & 6.52 & 7.43 & t.ha ${ }^{-1}$ \\
\hline $\begin{array}{l}\text { Adjusted straw } \\
\text { yield }\end{array}$ & 1.85 & 1.94 & 2.13 & 2.79 & 5.49 & 5.63 & 4.88 & 5.87 & 6.69 & $\begin{array}{l}10 \% \text { less than actual to } \\
\text { bring at farmer's level }\end{array}$ \\
\hline Gross benefit (b) & 6.51 & 6.83 & 7.53 & 9.85 & 19.38 & 19.86 & 17.21 & 20.71 & 23.60 & $3.53 \mathrm{US} \$ /$ ton \\
\hline Gross benefit $@$ & 642.63 & 746.32 & 678.11 & 937.52 & 1061.02 & 1045.6 & 1077.42 & 1186.93 & 1136.82 & Gross benefit $(a+b)$ \\
\hline Cost of DAP & 0 & 0 & 0 & 220.83 & 220.83 & 220.83 & 315.62 & 315.62 & 315.62 & $36.32 \mathrm{US} \$ / \mathrm{bag}$ \\
\hline Cost of Urea & 0 & 0 & 0 & 33.84 & 33.84 & 33.84 & 53.43 & 53.43 & 53.43 & $17.18 \mathrm{US} \$ / \mathrm{bag}$ \\
\hline Cost of PGPR & 0 & 4.91 & 4.91 & 0 & 4.91 & 4.91 & 0 & 4.91 & 4.91 & 4.91 US\$/ha \\
\hline Fixed cost & 550 & 550 & 550 & 550 & 550 & 550 & 550 & 550 & 550 & US\$./ha \\
\hline Cost that vary & 0 & 4.91 & 4.91 & 254.67 & 259.58 & 259.58 & 369.05 & 373.96 & 373.96 & US\$./ha \\
\hline Total cost & 550 & 554.91 & 554.91 & 804.67 & 809.58 & 809.58 & 919.05 & 923.96 & 923.96 & US\$./ha \\
\hline$*$ Net benefit & 92.63 & 191.41 & 123.19 & 132.85 & 251.45 & 236.02 & 158.37 & 262.97 & 212.85 & US\$./ha \\
\hline
\end{tabular}

T1=Non-inoculated control along with 0-0 $\mathrm{kg} \mathrm{ha}^{-1} \mathrm{~N}-\mathrm{P}$; T2=Inoculated with Bacillus sp. MWT-14 and 0-0 kg ha-1 N-P

T3=Inoculated with Pseudomonas sp. LYT-1 and 0-0 $\mathrm{kg} \mathrm{ha}^{-1} \mathrm{~N}-\mathrm{P}$; T4=Non-inoculated control with $105-70 \mathrm{~kg} \mathrm{ha}^{-1} \mathrm{~N}-\mathrm{P}$

T5=Inoculated with Bacillus sp. MWT-14 and 105-70 kg ha-1 N-P; T6=Inoculated with Pseudomonas sp. LYT-1 and 105-70 kg ha-1 N-P

T7=Non-inoculated control along with 150-100 kg ha ${ }^{-1} \mathrm{~N}-\mathrm{P} ; 8=$ Inoculated with Bacillus sp. MWT-14 and 150-100 kg ha-1 N-P

T9= Inoculated with Pseudomonas sp. LYT-1 and 150-100 kg ha-1 N-P

Table 9. Variable and fixed cost for economic analysis, Layyah.

\begin{tabular}{|c|c|c|c|c|c|c|c|c|c|c|}
\hline Treatment & $\mathbf{T}_{1}$ & $\mathbf{T}_{2}$ & $\mathbf{T}_{3}$ & $\mathbf{T}_{4}$ & $\mathbf{T}_{5}$ & $\mathbf{T}_{6}$ & $\mathbf{T}_{7}$ & $\mathbf{T}_{8}$ & $\mathbf{T}_{\mathbf{9}}$ & Remarks \\
\hline Grain yield & 2.21 & 2.59 & 2.4 & 3.5 & 4.03 & 3.94 & 4 & 4.34 & 4.2 & t.ha ${ }^{-1}$ \\
\hline $\begin{array}{l}\text { Adjusted } \\
\text { grain yield }\end{array}$ & 1.99 & 2.33 & 2.16 & 3.15 & 3.63 & 3.55 & 3.60 & 3.91 & 3.78 & $\begin{array}{l}10 \% \text { less than actual to bring at } \\
\text { farmer's level }\end{array}$ \\
\hline $\begin{array}{l}\text { Gross benefit } \\
\text { (a) }\end{array}$ & 585.76 & 686.48 & 636.12 & 927.68 & 1068.15 & 1044.30 & 1060.20 & 1150.32 & 1113.21 & $294.5 \mathrm{US} \$ /$ ton \\
\hline Straw yield & 1.85 & 1.90 & 1.89 & 3.10 & 3.57 & 3.64 & 3.56 & 4.30 & 4.35 & t.ha $\mathrm{A}^{-1}$ \\
\hline $\begin{array}{l}\text { Adjusted } \\
\text { straw yield }\end{array}$ & 1.67 & 1.71 & 1.70 & 2.79 & 3.21 & 3.28 & 3.20 & 3.87 & 3.92 & $\begin{array}{l}10 \% \text { less than actual to bring at } \\
\text { farmer's level }\end{array}$ \\
\hline $\begin{array}{l}\text { Gross benefit } \\
\text { (b) }\end{array}$ & 5.88 & 6.04 & 6.00 & 9.85 & 11.34 & 11.56 & 11.31 & 13.66 & 13.82 & $3.53 \mathrm{US} \$ /$ ton \\
\hline $\begin{array}{l}\text { Gross benefit } \\
\text { (c) }\end{array}$ & 591.64 & 692.52 & 642.12 & 937.52 & 1079.49 & 1055.86 & 1071.51 & 1163.98 & 1127.03 & Gross benefit $(a+b)$ \\
\hline Cost of DAP & 0 & 0 & 0 & 220.83 & 220.83 & 220.83 & 315.62 & 315.62 & 315.62 & 36.32 US\$/bag \\
\hline Cost of Urea & 0 & 0 & 0 & 33.84 & 33.84 & 33.84 & 53.43 & 53.43 & 53.43 & $17.18 \mathrm{US} \$ / \mathrm{bag}$ \\
\hline Cost of PGPR & 0 & 4.9 & 4.9 & 0 & 4.91 & 4.91 & 0 & 4.91 & 4.91 & $4.91 \mathrm{US} \$ / \mathrm{ha}$ \\
\hline Fixed cost & 550 & 550 & 550 & 550 & 550 & 550 & 550 & 550 & 550 & US\$./ha \\
\hline Cost that vary & 0 & 4.91 & 4.91 & 254.67 & 259.58 & 259.58 & 369.05 & 373.96 & 373.96 & US\$./ha \\
\hline Total cost & 550 & 554.91 & 554.91 & 804.67 & 809.58 & 809.58 & 919.05 & 923.96 & 923.96 & US\$./ha \\
\hline *Net benefit & 41.64 & 137.61 & 87.21 & 132.85 & 269.91 & 246.28 & 152.46 & 240.02 & 203.07 & US\$./ha \\
\hline $\begin{array}{l}\text { T1 }=\text { Non-inocu } \\
\text { T3=Inoculated } \\
\text { T5 }=\text { Inoculated } \\
\text { T7=Non-inocul }\end{array}$ & $\begin{array}{l}\text { lated con } \\
\text { with } P s e \\
\text { with } B a c \\
\text { ated con }\end{array}$ & 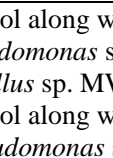 & $\begin{array}{l}\text { T-14 ar } \\
\text { h } 150-1\end{array}$ & $\begin{array}{l}05-70 \mathrm{k} \\
\mathrm{kg} \mathrm{ha}^{-1}\end{array}$ & $\begin{array}{l}2=\text { Inocula } \\
\mathrm{a}^{-1} \mathrm{~N}-\mathrm{P} ; \mathrm{T} \\
\mathrm{ha}^{-1} \mathrm{~N}-\mathrm{P} ; \\
\mathrm{P} ; \mathrm{T} 8=\mathrm{In}\end{array}$ & $\begin{array}{l}\mathrm{d} \text { with } B c \\
=\text { Non-ino } \\
=\text { Inocula } \\
\text { ulated } \mathrm{w}\end{array}$ & with Ps & $\begin{array}{l}T-14 \text { and } \\
\text { with } 105 \\
\text { lomonas } \mathrm{s} \\
\text { MWT-1 }\end{array}$ & $\begin{array}{l}0 \mathrm{~kg} \mathrm{ha}^{-1} \mathrm{~N} \\
0 \mathrm{~kg} \mathrm{ha}^{-1} \mathrm{~N} \\
\text { LYT-1 and } \\
\text { nd } 150-100\end{array}$ & $\begin{array}{l}P \\
P \\
105-70 \mathrm{~kg} \mathrm{ha}^{-1} \mathrm{~N}-\mathrm{P} \\
\mathrm{kg} \mathrm{ha}^{-1} \mathrm{~N}-\mathrm{P}\end{array}$ \\
\hline
\end{tabular}

fertilizer application which was far less when compared with that was obtained from inoculated treatment with zero NP fertilizer application at both the experimental sites. Inoculation of Pseudomonas LYT-1 in combination with all fertilizer levels gave higher net benefits as compared to the respective non-inoculated control treatments at both the experimental locations.
Conclusions: The bacterial strain Pseudomonas spp. LYT-1 along with different levels of NP improved the wheat productivity due to significant expansion in chlorophyll contents, crop allometric traits and along with elevated yield components. The Bacillus strain improved the 1000-grain weight and grain yield of wheat. Therefore these bacterial strains with NP fertilizer even at reduced level qualify for 
further field testing and may be considered as promising candidates for commercial biofertilizer.

\section{REFERENCES}

Abbasdokht, H. and A. Gholami. 2010. The effect of seed inoculation (Pseudomonas putida+Bacillus lentus) and different levels of fertilizers on yield and yield components of wheat (Triticum aestivum L.) cultivars. World Aced. Sci. Eng. Technol. 68:979-983.

Abd-El-Haleem, S., M. Reham and S. Mohamed. 2009. Genetic analysis and RAPD polymorphism in some durum wheat genotypes. Global J. Biotechnol. Biochem. 4:1-9.

Babana, A.H., H. Antoun, A.H. Dicko, K. Maïga and D. Traoré. 2012. Effect of Pseudomonas sp. on wheat roots colonization by mycorhizal fungi and phosphatesolubilizing microorganisms, wheat growth and Puptake. J. Microbiol. 1:1-7.

Bahulikar, R.A., I. Torres-Jerez, E. Worley, K. Craven and M.K. Udvardi. 2014. Diversity of nitrogen-fixing bacteria associated with switchgrass in the native tallgrass prairie of Northern Oklahoma. Appl. Environ. Microbiol. 80:5636-5643.

Baldani, J.I., V.M. Reis, S.S. Videira, L.M. Boddey and V.L.D. Baldani. 2014. The art of isolating nitrogen-fixing bacteria from non-leguminous plants using N-free semisolid media: a practical guide for microbiologists. Plant Soil 384:413-431.

CIMMYT. 1988. From Agronomic Data to Farmer Recommendations: An Economics Training Manual. Completely revised edition, Mexico.

Gupta, S., M.K. Meena and S. Datta. 2014. Isolation, characterization of plant growth promoting bacteria from the plant Chlorophytum borivilianum and in-vitro screening for activity of nitrogen fixation, phospthate solubilization and IAA production. Int. J. Curr. Microbiol. App. Sci. 3:1082-1090.

Haahtela, K., T. Wartiovaara, V. Sundman and J. Skujins. 1981. Root-associated $\mathrm{N}_{2}$ fixation (acetylene reduction) by Enterobacteriaceae and Azospirillum strains in coldclimate spodosols. Appl. Environ. Microbiol. 41:203206.

Hunt, R. 1978. Plant growth analysis, pp-26-38. Edward Arnold, Ollondon, UK.

Hussain, M., G. Shabir, M. Farooq, K. Jabran and S. Farooq. 2012a. Developmental and phenological responses of wheat to sowing dates. Pak. J. Agric. Sci. 49:1-10.

Hussain, M., M. Farooq, G. Shabir, M.B. Khan and A.B. Zia. 2012b. Delay in planting decreases wheat productivity. Int. J. Agric. Biol. 14:533-539.

Hussain, M., M. Waqas-ul-Haq, S. Farooq, K. Jabran and M. Farooq. 2016. The impact of seed priming and row spacing on the productivity of different cultivars of irrigated wheat under early season drought. Exp. Agric. Incomplete

Hussain, S., I.U. Khan, A. Sattar, A. Sher, M. Ijaz, M.M. Iqbal, A. Areeb and M. Irfan. 2016. Influence of different methods and time of phosphorus fertilizer application in wheat under arid condition. J. Glob. Innov. Agric. Soc. Sci. 4(1): 8-14.

Khan, A.A., G. Jilani, M.S. Akhtar, S.M.S. Naqvi and M. Rasheed. 2009. Phosphorus solubilizing bacteria: occurrence, mechanisms and their role in crop production. J. Agric. Biol. Sci. 1:48-58.

Kibe, A., S. Singh and N. Kalra. 2006. Water-nitrogen relationships for wheat growth and productivity in late sown conditions. Agric. Water Manage. 84:221-228.

Kumar, G.P., N. Kishore, E.L.D. Amalraj, S.M.H. Ahmed, A. Rasul and S. Desai. 2012. Evaluation of fluorescent Pseudomonas spp. with single and multiple PGPR traits for plant growth promotion of sorghum in combination with AM fungi. Plant Growth Regul. 67:133-140.

Ladha, J., F. De Bruijn and K. Malik. 1997. Introduction: assessing opportunities for nitrogen fixation in rice-a frontier project. Plant Soil 194:1-10

Malik, K., R. Bilal, S. Mehnaz, G. Rasul, M. Mirza and S. Ali. 1997. Association of nitrogen-fixing, plant-growthpromoting rhizobacteria (PGPR) with kallar grass and rice. Plant and Soil 194:37-44.

Mehnaz, S. 2015. Azospirillum: A biofertilizer for every crop. In: Plant Microbes Symbiosis: Applied Facets. Springer. pp.297-314.

Mehnaz, S., M.S. Mirza, J. Haurat, R. Bally, P. Normand, A. Bano and K.A. Malik. 2001. Isolation and 16S rRNA sequence analysis of the beneficial bacteria from the rhizosphere of rice. Can. J. Microb. 47:110-117.

Mirza, B.S., C. Potisap, K. Nusslein, B.J. Bohannan and J.L. Rodrigues. 2014. Response of free-living nitrogen-fixing microorganisms to land use change in the Amazon rainforest. Appl. Environ. Microbiol. 80:281-288.

Murphy, J. and J.P. Riley.1962. Modified solution method for determination of phosphate in natural water. Ann. Chim. Acta 27:31-36.

Okon, Y., S.L. Albercht and R.H. Burris. 1977. Methods for growing Spirillum lipoferum and for counting it in pure culture and in association with plants. Appl. Environ. Microbiol. 33:85-88.

Panhwar, Q.A., R. Othman, Z.A. Rahman, S. Meon and M.R. Ismail. 2014. Isolation and characterization of phosphatesolubilizing bacteria from aerobic rice. Afr. J. Biotech. 11:2711-2719.

Pastor, N., S. Rosas, V. Luna and M. Rovera. 2014. Inoculation with Pseudomonas putida $\mathrm{PCI}_{2}$, a phosphate solubilizing rhizobacterium, stimulates the growth of tomato plants. Symbiosis 62:157-167. 
Perez, E., M. Sulbaran, M.M. Ball and L.A.Yarzabal. 2007. Isolation and characterization of mineral phosphatesolubilizing bacteria naturally colonizing a limonitic crust in the south-eastern Venezuelan region. Soil Biol. Biochem. 39:2905-2914.

Pikovskaya, R. 1948. Mobilization of phosphorus in soil in connection with vital activity of some microbial species. Mikrobiol. 17:362-370.

Rehim, A., M. Hussain, M. Abid, M. Zia-ul-Haq and S. Ahmad. 2012. Phosphorus use efficiency of Triticum aestivum L. as affected by band placement of phosphorus and farmyard manure on calcareous soils. Pak. J. Bot. 44:1391-1398.

Rehman. K., S. Ali, M.W. Pervez, M. Rehman, S. Hussain, G. Aishia and M.S. Khalid. 2014. Performance of autumn planted maize hybrids under different fertilizer treatments in semi-arid Punjab-Pakistan. J. Glob. Innov. Agric. Soc. Sci., 2(3): 107-111.

Rennie, R., J. De Freitas, A. Ruschel and P. Vose. 1982. Isolation and identification of $\mathrm{N}_{2}$-fixing bacteria associated with sugar cane (Saccharum sp.). Can. J. Microbiol. 28:462-467.

Richardson, A.E. 2001. Prospects for using soil microorganisms to improve the acquisition of phosphorus by plants. Funct. Plant Biol. 28:897-906.

Richardson, A.E., J.M. Barea, A.M. McNeill and C. PrigentCombaret. 2009. Acquisition of phosphorus and nitrogen in the rhizosphere and plant growth promotion by microorganisms. Plant Soil 321:305-339.

Sattar, A., M.A. Cheema, M. Farooq, M.A. Wahid, A. Wahid and B.H. Babar. 2010. Evaluating the performance of wheat cultivars under late sown conditions. Int. J. Agric. Biol. 4:561-565.

Shah, M.A., A. Manaf, M. Hussain, S. Farooq and M. Zafarul-Hye. 2013. Sulphur fertilization improves the sesame productivity and economic returns under rainfed conditions. Int. J. Agric. Biol. 15:1301-1306.

Shahid, M., S. Hameed, A. Imran, S. Ali and J.D. van Elsas. 2012. Root colonization and growth promotion of sunflower (Helianthus annuus L.) by phosphate solubilizing Enterobacter sp. Fs-11. World J. Microbiol. Biotechnol. 28:2749-2758.

Shahid, M., S. Hameed, M. Tariq, M. Zafar, A. Ali and N. Ahmad. 2014. Characterization of mineral phosphatesolubilizing bacteria for enhanced sunflower growth and yield-attributing traits. Ann. Microbiol. 10:1-12.

Shridhar, B.S. 2012. Review: Nitrogen Fixing Microorganisms. Int. J. Microbiol. Res. 3:46-52.

Steel, R.G.D., J.H. Torrie and D.A. Dickey. 1997. Principles and procedures of statistics: A biometric approach. McGraw-Hill, New York.

Tahir, M., M.S. Mirza, A. Zaheer, M.R. Dimitrov, H. Smidt and S. Hameed. 2013. Isolation and identification of phosphate solubilizer Azospirillum, Bacillus and Enterobacter strains by 16SrRNA sequence analysis and their effect on growth of wheat (Triticum aestivum L.). Aust. J. Crop Sci. 7:1284-1292.

Tahir, M., M.S. Mirza, S. Hameed, M.R. Dimitrov and H. Smidt. 2015. Cultivation-based and molecular assessment of bacterial diversity in the rhizosheath of wheat under different crop rotations. PloS One 10. doi: 10.1371/journal.pone.0130030.

Tarrand, J.J., N.R Krieg and J. Döbereiner. 1978. A taxonomic study of the Spirillum lipoferum group, with descriptions of a new genus, Azospirillum gen. nov. and two species, Azospirillum lipoferum (Beijerinck) comb. nov. and Azospirillum brasilense sp. Nov. Can. J. Microbiol. 24:967-980.

Tien, T., M. Gaskins and D. Hubbell. 1979. Plant growth substances produced by Azospirillum brasilense and their effect on the growth of pearl millet (Pennisetum americanum L.). Appl. Environ. Microb. 37:1016-1024.

Walker, T.S., H.P. Bais, E. Grotewold and J.M. Vivanco. 2003. Root exudation and rhizosphere biology. Plant Physiol. 132:44-51.

Weisburg, W.G., S.M. Barns, D.A. Pelletier and L. De. 1991. $16 \mathrm{~S}$ ribosomal DNA amplification for phylogenetic study. J. Bacteriol. 173:697-703. 